\title{
Monopolizing the Property of Skill: A Prosopographic Analysis of a Finnish Ironworks Community
}

\author{
JuUso MARTtila \\ Department of History and Ethnology, University of Jyväskylä \\ E-mail: juhamart@jyu.fi
}

Summary: This article examines the survival of artisan labour structures and their property of skill in a case where neither a guild nor a union was present. Both of these institutions have traditionally been given as explanations for the survival of artisan labour structures and their property of skill. By using a prosopographic analysis of a Finnish ironworks community, this article follows a locally monopolized property of skill from i880 to 1950. This monopoly was based on an informal apprenticeship system and the control of human capital, and was tied tightly to a closed network of smiths and their families. It was able to function in full force without the backing of any formal institutions as long as favourable local circumstances and the means and motivation to maintain it existed. Family relationships and social networks of smiths, together with the acceptance of patronage, functioned as an alternative to trade unions and guilds as primary strategic resources resorted to by smith households.

\section{INTRODUCTION}

Craftsmanship was an important asset for artisans throughout both the pre-industrial and the industrial ages. Much research in economic history has focused on the importance and fate of this property during the industrialization process. Studies have found enduring artisan labour structures, for example the exclusion of outsiders from occupations, wage premiums, and freedom from management interference on the shop floor. Traditional explanations for the persistence of these pre-industrial structures have assigned a huge importance to craft-based unions, especially in the British context. As argued by Eric Hobsbawm, John Rule, William Lazonick, Isaac Cohen, David Montgomery, and a plethora of other scholars, artisans were important in establishing these unions, and reciprocally the unions were crucial in maintaining the status of artisans, or skilled workers, and their

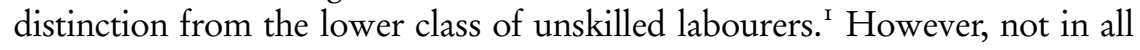
John Rule, "The Property of Skill in the Period of Manufacture", in Patrick Joyce (ed.), 
cases were craft or trade unions or formal institutions such as guilds necessary for maintaining the continued existence of a labour aristocracy based on craft skills. In particular, the continued monopolization of artisanal skills by kin networks, in certain cases without any further institutional protection, provides an interesting addition to our understanding of mechanisms that shaped early industrial labour structures.

This article presents a case study in which a group of artisan families were able to monopolize, maintain, and, more importantly, transmit their skills and the socio-economic position bound up with those skills. It argues that, in the case of ironworks communities, the smiths' monopolization of the property of skill, as described by both Hobsbawm and Rule, was not really threatened by either their complete lack of unionism or the abolition of the formal guild institution, nor through any other legal changes. In the absence of institutional protection, local circumstances, i.e. the organization of work, the patriarchal management system, the mutual solidarity of the smiths, their artisanal traditions and identity, the lack of alternative training, and the supply of, and demand for, both skill and forged iron were major factors. This case can therefore add to our knowledge of how early industrial labour structures could function outside the more researched sphere of guilds and trade unions.

In order to establish its research territory, this article first provides a brief survey of the role of artisans and their skills in the industrialization process. It then presents a research setting and a case study of a Finnish ironworks community from I 880 to 1950 in which the importance of skill, the living inheritance of skilled occupations, and the persistence of artisan labour structures linked with strong kin endogeneity are confirmed. The article goes on to examine why this monopolized property of skill continued to exist locally in spite of the absence of formal institutions.

\section{ARTISANS' CONTROL OF THEIR CRAFT AND SKILL IN THE INDUSTRIALIZATION PROCESS}

Economic history has long been interested in studying the effects of industrialization on formerly artisan-controlled trades and the fates of

The Historical Meanings of Work (Cambridge, 1989), pp. 99-1 18; Isaac Cohen, "Workers' Control in the Cotton Industry: A Comparative Study of British and American Mule Spinning", Labor History, 26 (1985), pp. 53-85; David Montgomery, Workers' Control in America: Studies in the History of Work, Technology, and Labor Struggles (London, 1979), pp. 10-27; William Lazonick, "Industrial Relations and Technical Change: The Case of the Self-acting Mule", Cambridge Journal of Economics, 3 (1979), pp. 23 I-262. On the role of artisans in the labour movement outside England see, for example, Friedrich Lenger, "Beyond Exceptionalism: Notes on the Artisanal Phase of the Labour Movement in France, England, Germany and the United States", International Review of Social History, 36 (199I), pp. I-23; Christiane Eisenberg, "Artisans' Socialization at Work: Workshop Life in Early Nineteenth-Century England and Germany", Journal of Social History, 24 (1991), pp. 507-520. 
artisans themselves. The roots of this discussion lie in the acknowledgement of the human factor in labour power, as noted by Harry Braverman in the early I970s, when he stated that the infinite potential of labour power was limited in its realization by the subjective state of the workers. ${ }^{2}$ This kind of approach also made it possible to identify the significance of artisans and their skills in the industrialization process, although Braverman himself argued that the craft status of skilled workers was weakened by the introduction of machinery.

The debate concerning artisans and industrialization has moved a long way from the late I970s, when Raphael Samuel, a Marxist himself, felt impelled to launch an extensive attack on the Marxists' belief in mechanization and de-skilling and defend the role that both artisans and their skills had played in industrialization. In his essay, Samuel emphasized that manual technology and craft skill had been needed throughout the nineteenth century and that much of the artisanal heritage had been maintained even in factories. ${ }^{3}$ This view was supported by Richard Price, who likewise pointed to the high levels of individual skills that survived. ${ }^{4}$ Following Samuel and Price, scholars have widely acknowledged the importance of both artisans' skills and their heritage in industrialization, and they have become a standard part of the debate about the creation of the working class. This can be seen, for example, in Hobsbawm's works on British labour and the labour aristocracy, and it is encapsulated in John Smail's remark that "early phases of industrialization were accomplished within the terms of an artisanal culture".

Craft skills have been at the heart of the discussion concerning artisans and their fate during the process of industrialization. This is very understandable when one sees skill as a form of property, as both Rule and Hobsbawm do. The property of skill refers to artisans' sense of their skills as property, for which a rent justly accrued and which formed a

\footnotetext{
2. Harry Braverman, Labor and Monopoly Capital: The Degradation of Work in the Twentieth Century (New York, 1974), p. 39.

3. Raphael Samuel, "The Workshop of the World: Steam Power and Hand Technology in Mid-Victorian Britain”, History Workshop Journal, 3 (1977), pp. 6-72.

4. Richard Price, "Structures of Subordination in Nineteenth-Century British Industry", in Pat Thane, Geoffrey Crossick, and R.C. Floud (eds), The Power of the Past: Essays for Eric Hobsbawm (Cambridge, I984), pp. I19-I42.

5. Eric Hobsbawm, "The Labor Aristocracy of Nineteenth-Century Britain", in Peter N. Stearns and Daniel J. Walkowitz (eds), Workers in the Industrial Revolution (New Brunswick, NJ, 1974), pp. I38-176; Hobsbawm, Workers: Worlds of Labor; John Smail, "Manufacturer or Artisan? The Relationship between Economic and Cultural Change in the Early Stages of the Eighteenth-Century Industrialization", Journal of Social History, 25 (1992), pp. 791-8 I4. The importance of craftsmanship on industrialization has recently been discussed in, for example, Joel Mokyr and Hans-Joachim Voth "Understanding Growth in Europe, I700-I870: Theory and Evidence", in Stephen Broadberry and Kevin H. O'Rourke (eds), The Cambridge Economic History of Modern Europe, I: $1700-1870$ (Cambridge, 2010), pp. 7-42, 3 I-32.
} 
considerable part of the artisanal identity. It was also regarded as a family heritage, which, wherever possible, was passed down to the next generation. For a long time, apprenticeship played a crucial role in this process as craft skills were not acquired at educational institutions. For many, the ability to preserve their status and welfare was more important than independence in employment. This experience and the higher, or at least more secure, income that a skill provided were important in uniting artisans as labour aristocrats. ${ }^{6}$ This shows how fundamental a property skill was for craftsmen, and later for skilled workers. In line with this, categories such as "skilled" and "unskilled" took on meanings that extended deep into the social order of communities, as Ben Maddison later put it. ${ }^{7}$ Thanks to their property of skill and its reproduction, artisans survived, if not as traditional craftsmen, at least as skilled workers, to become the new aristocracy of labour. ${ }^{8}$

As Richard Price stated, the technology of the Industrial Revolution did not succeed in destroying this property, but rather caused its recomposition, leaving workers viable bases from which to retain or create certain forms of protection. ${ }^{9}$ Here, the artisans' control of the skill, and thus of the craft, has been the aspect most closely scrutinized in the academic debate, since their influence on the industrialization process and their ability to cope with it depended on their craft skill and their control of that skill. An important component in this was the traditional freedom of craftsmen on the shop floor, which was carried over into machine workshops. This has been extensively studied, especially in the context of the British textile industry, and both Lazonick and Cohen give much weight to the subcontracting system and the lack of supervision of the work or the delegation of supervision to skilled workers themselves. This was close to the old artisanal organization of work. Anders Florén found a similar trend in Swedish ironworks. Here it is important to note that in many cases this procedure was not contrary to the interests of the management. ${ }^{\mathrm{I}}$

6. Hobsbawm, Workers: Worlds of Labor, pp. 238, 257-258, 262, 264-265; Rule, "The Property of Skill in the Period of Manufacture", pp. IO2-IO4; Mokyr and Voth, "Understanding Growth in Europe", p. 3 I. On the significance of income, see also Cohen, "Workers' Control in the Cotton Industry", pp. 64-66.

7. Ben Maddison, "Labour Commodification and Skilled Selves in Late Nineteenth-Century Australia", International Review of Social History, 43 (1998), pp. 265-286, 285. On the segregation between skilled and unskilled labour, see also Rule, "The Property of Skill in the Period of Manufacture", p. i i 8.

8. Hobsbawm, Workers: Worlds of Labor, p. 254; Rule, "The Property of Skill in the Period of Manufacture", pp. I02-103.

9. Price, "Structures of Subordination in Nineteenth-Century British Industry".

Iо. Anders Florén, "Social Organization of Work and Labour Conflicts in Proto-Industrial Iron Production in Sweden, Belgium and Russia", International Review of Social History, 39 
Artisans, who often retained what Marcel van der Linden calls a "domain of control" - in other words, were in a position to close off a segment of the labour marker - were able to exert this power through unions. ${ }^{\text {II }}$ Thus, research on artisan craft control has given great emphasis to trade unions, which links the subject to labour history. At least in the United States, Germany, France, and Britain, the early labour movements were dominated by urban artisans. ${ }^{\mathrm{I}}$ Particularly in the above studies by Lazonick, Rule, Montgomery, Cohen, and also Hobsbawm, unions controlled by artisans were given a crucial role in craft control. They have been seen in the British textile industry as even the only means of maintaining the relative exclusiveness - with respect to both non-skilled workers and women - of the labour aristocracy and its autonomy on the shopfloor. They did so, for example, by providing mutual support, protecting the subcontracting system which permitted this autonomy, and by resisting technological change. In this process, collective action replaced regulation by the state or a corporation. ${ }^{\text {I3 }}$

One alternative to the guilds and unions is offered by other strategic resources for the improvement of their conditions that smiths' households had at their disposal. Falling back on family relationships and other local networks was an important strategic option, and these networks could possess, transmit, and, in some cases, even monopolize the property of skill. Even in the age of the guilds, the family had been recognized as a secure structure for exerting control over a craft, and this had led to a strong occupational endogeneity. ${ }^{\mathrm{I}}{ }^{4}$ As noted above on the property of

(1994), pp. 83-II3; Lazonick, "Industrial Relations and Technical Change”, p. 233; Cohen, "Workers' Control in the Cotton Industry", pp. 59-62, 69. On the importance of freedom, see Hobsbawm, Workers: Worlds of Labor, p. 238. See also Price, "Structures of Subordination in Nineteenth-Century British Industry”.

I I. On control in the unionization process see, inter alia, Marcel van der Linden, Workers of the World: Essays Toward a Global Labor History (Leiden, 2008), pp. 229-244.

I2. A good summary of this can be found in Lenger, "Beyond Exceptionalism". It is also important to note that this held true also in Finland, although the case of Strömfors was exceptional. See Risto Alapuro, Suomen synty paikallisena ilmiönä, I 890-I933 (Helsinki, I995), pp. 74-80; idem and Henrik Stenius, "Kansanliikkeet loivat kansakunnan", in Risto Alapuro, Ilkka Liikanen, Kerstin Smeds, and Henrik Stenius (eds), Kansa liikkeessä (Helsinki, I987), pp. $8-49,33-37$.

I3. Cohen, "Workers' Control in the Cotton Industry", p. 85; Hobsbawm, Workers: Worlds of Labor, pp. I 83, 235, 256, 259; Lazonick, "Industrial Relations and Technical Change", p. 249; Robert Leeson, Travelling Brothers: The Six Centuries' Road from Craft Fellowship to Trade Unionism (London, 1979); Montgomery, Workers' Control in America; Rule, “The Property of Skill in the Period of Manufacture", pp. I0I, I I6. On differences in unions caused by different guild organizations in European countries, see Eisenberg, "Artisans' Socialization at Work". I4. Marcel van der Linden, "Connecting Household History and Labour History", International Review of Social History, 38 (1993), Supplement I, pp. I63-I73, I70. Giorgio Riello, "The Shaping of a Family Trade: The Cordwainers' Company in Eighteenth-Century London”, 
skill as a family heritage, this occupational endogeneity persisted in some trades after industrialization. For example, Michael Anderson found plenty of evidence of this in his studies of family structure in Lancashire. According to Anderson, a common characteristic of these sectors was that the organization of work in them employed young assistants or involved jobs where an apprenticeship-like system was needed for teaching. A similar development was to be found in various trades and in other locations, sometimes backed up by trade-union regulations but also sometimes without any formal institutional protection. ${ }^{\text {Is }}$

\section{RESEARCH SETTING AND METHOD}

In the spirit of the social history of labour, and following Van der Linden in his pioneering work on connecting household history to labour history, we must look at the "private sphere" in order to reveal local inheritance structures and other less obvious alternatives to institutional protection, such as kinship, personal communities, and the acceptance of patronage. As these are limited to specific contexts, they are harder to capture in nationwide macro-level studies, which in labour history, according to Van der Linden, have often failed to give the influence of location on human actions the consideration it deserves. Thus, an actor-level analysis is needed to make these subjective everyday motives and experiences visible and then connect them with institutional history. ${ }^{16}$

When studying the details of early industrialization, Nordic scholars have long focused on the ironworks industry. In the absence of a significant textile industry in comparison with central and north-western Europe, the metal industry, represented in the nineteenth century mostly by ironworks, was among the most important sectors both in Sweden and

in Ian Anders Gadd and Patrick Wallis (eds), Guilds, Society E Economy in London 1450-I800 (London, 2002), pp. I4I-I 59, I 54. For an example of family dynasties in the context of guilds, see Johan Dambruyne, "Guilds, Social Mobility and Status in Sixteenth-Century Ghent", International Review of Social History, 43 (1998), pp. 31-78, 72-73.

I 5. Michael Anderson, Family Structure in Nineteenth Century Lancashire (Cambridge, 1971), pp. 116-121; Geoffrey Crossick, An Artisan Elite in Victorian Society: Kentish London I840-I880 (London, I978), p I 16; Hobsbawm, Workers: Worlds of Labor, pp. 264-265. For a Finnish example in the glass industry, see Virpi Nurmi, Lasinvalmistajat ja lasinvalmistus Suomessa I900-luvun alkupuolella (Helsinki, 1989). On the inheritance of an industrial occupation that continued far into the twentieth century, see Anne-Marie Greene, Peter Ackers, and John Black, "Going Against the Historical Grain: Perspectives on Gendered Occupational Identity and Resistance to the Breakdown of Occupational Segregation in Two Manufacturing Firms", Gender, Work E Organization, 9 (2002), pp. 266-285, 281; Margaret Grieco, "Family Networks and the Closure of Employment", in Gloria Lee and Ray Loveridge (eds), The Manufacture of Disadvantage (Philadelphia, PA, 1987), pp. 33-44.

I6. Van der Linden, "Connecting Household History and Labour History", pp. I63, I69-172; idem, "Editorial", International Review of Social History, 38, Supplement I (1993), pp. I-3. 
in Finland. The micro-historical approach in the study of ironworks and their communities has made it possible to deal with notable historical problems related to industrialization: for example, the effects that ironworks had on the surrounding population, the role of manufacturing industry in proto-industrialization, and social institutions. The household, its life cycle, and its connection with work in ironworks communities have also been studied, which indicates that it is a good research setting for the task at hand. ${ }^{17}$

Ironworks communities were traditionally stable hierarchical societies characterized by clear occupation-based social and economic segregation. This segregation had long been maintained by patriarchal management and by the guild-like legislation regulating the smiths' craft, which was the main element of the production process. Ironworks were also regulated by legal privileges and were both institutionally and spatially isolated, as well as being notably different from the agrarian society surrounding them. The unique nature of the work in the forges and the other industrial workshops of the ironworks company was a major life-shaping factor that strongly influenced even such institutions as households and gender roles in the community. Work for the ironworks company united the community in that every member of it was supposed to act so as to benefit the owner of the ironworks in some way. The work also segregated people, since both occupation and status were usually transmitted from father to son, and occupational endogamy flourished. Together with institutionalized apprenticeship and the journeyman system, this had led to the monopolization of skilled occupations by certain families and to the birth of a property of skill. ${ }^{8}$

From the latter half of the nineteenth century onwards, ironworks underwent a long and gradual process of industrialization and modernization.

17. A brief introduction to research on ironworking in the Nordic countries and especially its relation to studies on industrialization and proto-industrialization can be found in Maria Agren, "Introduction: Swedish and Russian Iron-Making as Forms of Early Industry", in idem (ed.), Iron-Making Societies: Early Industrial Development in Sweden and Russia, I600-1900 (Oxford, 1998), pp. 3-32. On the relationship between the occupation of the smith and the household, see Göran Rydén, Hammarlag och hushaill. Om relationen mellan smidesarbetet och smedshushaillen vid Tore Petrés brukskomplex I830-I850 (Uppsala, I990); idem with Svetlana Golikova, "Households, Families and Iron-making", in Agren, Iron-Making Societies, pp. $218-246$.

I8. On ironworks societies generally, see Kustaa H.J. Vilkuna, Arkielämää patriarkaalisessa työmiesyhteisössä. Rautarunkkilaiset suurvalta-ajan Suomessa (Helsinki, 1996). On households, see Rydén, Hammarlag och hushaill; idem and Golikova, "Households". On gender roles, see Anders Florén, Genus och producentroll. Kvinnoarbete inom svensk bergshantering, exemplet Jäders bruk I640-I840 (Uppsala, I99I). On Finnish ironworks, see Kustaa H.J Vilkuna, Valtakunnan eduksi, isänmaan kunniaksi, runkinpatruunalle byödyksi. Suomen rautateollisuus suurvalta-ajalle (Helsinki, I994). On their social order and everyday life, see Georg Haggrén, Hammarsmeder, masugnsfolk och kolare. Tidigindustriella yrkesarbetare vid provinsbruk $i$ i600-talets Sverige (Stockholm, 200I). 
Using communities of this kind as a research setting can supplement previous research on ironworks, and thus offer an opportunity for an analysis of issues related to craft skill. The problems encountered by skilled workers in this kind of environment were in many respects similar to those faced by the much-researched British and American mule spinners. Subcontracting, a lack of supervision or supervision delegated to skilled workers themselves, piece-wages, and notable wage differentials featured in both cases. ${ }^{19}$ Naturally, there were also differences, most notably the relatively small size of Nordic ironwork communities and their location in the countryside. ${ }^{20}$

The specific case for this study is the Strömfors Ironworks community in Finland during the years I880-1950. The Strömfors Ironworks was established in I695 in southern Finland, around roo kilometres east of Helsinki. Until the late nineteenth century, its core industries employed Io to 20 smiths in forges and a few other skilled workers in a mill, a lumber mill, and in charcoal production. There were also 20 to $30 \mathrm{mis}-$ cellaneous unskilled labourers, most of them employed in the lumber mill and a small brickworks. Both the size and number of the different industrial units in Strömfors were fairly typical of ironworks of the time. In the I 870 s, an increasing number of traditional ironworks proprietors found themselves in financial difficulties. Thus, in Strömfors too, the ownership basis of the ironworks changed, and a single patriarchal owner was replaced by a short-lived corporation, before a notable Finnish captain of industry, Antti Ahlström, bought the plant from the bankrupt estate. In 1907 Ahlström's holdings were incorporated into a limited company, A. Ahlström Oy, of whose total turnover Strömfors accounted for about one-tenth. Despite the new ownership, the local management still maintained the old paternalistic customs as links with the mother company's management were at best tenuous, and the company itself was interested mostly in the timber resources and the lumber mill at Strömfors. ${ }^{2 \mathrm{I}}$

By the turn of the century, the traditional manufacturing-based ironworking industry was becoming increasingly marginal across the country, as can be seen in Table $\mathrm{I} .{ }^{22}$ This induced the management of Strömfors too to shift its focus from the forges to the lumber mill at a time when the Finnish forest industry generally was beginning to boom. At the same time, the production of iron goods - mostly nails, axes, and other tools of the

19. Cohen, "Workers' Control in the Cotton Industry", pp. 59-66.

20. Rydén and Golikova, "Households", p. 234.

21. Olle Sirén, Strömfors. Tehdas ja tebdasybdyskunta I695-1970 (Helsinki, I97I). On Antti Ahlström and A. Ahlström $\mathrm{Oy}$, see Per Schybergson, Työt ja päivät: Ablströmin historia I85I-I98I (Helsinki, I992).

22. On industrialization in general in Finland see Riitta Hjerppe, The Finnish Economy I860-1985: Growth and Structural Change (Helsinki, I989). 
Table I. Data on Strömfors and Finnish ironworks

\begin{tabular}{lcccc}
\hline Decade & $\begin{array}{c}\text { Smiths at } \\
\text { Strömfors }\end{array}$ & $\begin{array}{c}\text { Total number of } \\
\text { employees and their } \\
\text { families at Strömfors }\end{array}$ & $\begin{array}{c}\text { Traditional } \\
\text { ironworks in } \\
\text { Finland* }\end{array}$ & $\begin{array}{c}\text { Average number of } \\
\text { employees in Finnish } \\
\text { industry per facility }\end{array}$ \\
\hline 1880 & c. 20 & c. 60 & 45 & $33^{* *}$ \\
1910 & c. 20 & c. 160 & 15 & 46 \\
1940 & c. 10 & n/a & 1 & 50 \\
\hline
\end{tabular}

* The figures refer only to ironworks still producing forged iron, others having been closed or transformed to accommodate more modern forms of the iron industry.

** This figure is for the year I $890 /$ I 89 I.

Sources: Prosopographic Database for Strömfors; Mirja Turunen (ed.), Ruukkien retki. Historic Ironworks of Finland (Tampere, 1998), pp. 163-164; Riitta Hjerppe, Suurimmat yritykset Suomen teollisundessa I844-1975 (Helsinki, I979).

time - declined in Strömfors, although not linearly, as both world wars saw an increase in demand for them. This is very similar to the developments seen in other ironworks communities. This development also changed the social environment of the Strömfors Ironworks community considerably as the number of labourers in the sawmill increased from a few employees in the I 870 s to eighty in the I920s, thus notably exceeding the declining number of smiths, who had previously dominated the population of the ironworks community both numerically and in terms of social status. In addition to these, there was also a handful of families not employed by the company. ${ }^{23}$

Strömfors itself provides a good research setting because traditional ironworking, which relied on the skills of individual smiths, survived there after all other ironworks in Finland and most of those in Sweden, too, had closed down. In Strömfors, the fate of the property of skill can be examined from the days of the guilds right up until the mid-twentieth century. One might have expected unionism to have been firmly established for decades by then, while it actually remained absent. Indeed, there was no active workers' union in Strömfors before World War II. This gives us a rare opportunity to study how the property of skill and craft closure could exist without institutional protection. In some other late-surviving ironworks, such as Ramnäs in Sweden, workers' unions played a significant role, with smiths as their leading figures. ${ }^{24}$ The longterm framework offered by Strömfors makes it easier to examine slowly changing factors, such as kinship, connected with the property of skill.

In order to study the local property of skill and those who possessed it in the Strömfors Ironworks community, I have used a prosopographic

23. Sirén, Strömfors.

24. On trade unions at Swedish ironworks see, inter alia, Åke Lindström, Bruksarbetarfackföreningar.

Metalls avdelningar vid bruken i östra Väsmanlands län före I9II (Uppsala, 1979). 
analysis of the local population. ${ }^{25}$ This requires a complete database of all residents, including their family connections and occupations. Thus, the core of the source material consists of records from Ruotsinpyhtää (Strömfors) church archives, which provide data on the family relationships and occupational status of the community's inhabitants. Data of this kind have been used quite frequently in historical studies of microlevel social mobility and the transmission of human capital in Nordic countries. ${ }^{26}$ The data for Strömfors have been compiled into a single database, which has then been used to ascertain the occupations of the inhabitants. These occupational data are then collated with information about the smiths' social connections, which can be traced from marriage registers and, to a much greater extent, from godparent connections, which constitute a good indicator of local social networks. ${ }^{27}$ Even if the quantity of data in the database might seem insufficient as a statistical basis for research, those data do still cover the whole community.

Moreover, although at first sight unskilled workers seem absent from the analysis, that absence is merely a result of the fact that they did not achieve the status of skilled worker and it is not due to a lack of information about them. The only individuals employed in the forges were genuinely skilled workers or their apprentices, and hence the empirical material concentrates on smiths. To gain some understanding of the private sphere, the data are supplemented with ethnographic material gathered from the locality. This material consists of a miscellaneous collection of interviews with former employees of the ironworks that were made for various purposes between the I960s and 2006. Before going into the conclusions to be drawn from these sources, it is necessary first to establish the role of skill and its control in ironworks communities from the guild period to the twentieth century.

\section{SKILL IN TRADITIONAL IRONWORKS COMMUNITIES}

Traditionally, the most important and profitable products of an ironworks company were iron and iron goods, and these simply could not be produced without the skills of smiths. Both the quality and the transmission of these

25. On prosopographical methodology, see K.S.B. Keats-Rohan (ed.), Prosopography-Approaches and Applications: A Handbook (Oxford, 2007).

26. Among recent works, see for example Martin Dribe and Patrick Svensson, "Social Mobility in Nineteenth Century Rural Sweden - A Micro Level Analysis", Scandinavian Economic History Review, 56 (2008), pp. I22-I4I; Johan A. Lundin, Näten på Limbamn: Sociala relationer $i$ ett lokalsambälle $1870-1914$ (Lund, 2006).

27. This Prosopographic Database for Strömfors (PDS) is based on baptismal registers (I860-1950), marriage registers (I860-1950), and communion records (1860-1914) in the Ruotsinpyhtää (Strömfors) church archives in Loviisa. All subsequent source data on local individuals are taken from the PDS and not referenced again. 
skills were, in principle, controlled by the laws governing the guild. At the local level, there was usually not a single person in the company apart from the smiths who would have possessed the technical skills to work in the forges.

Even though the processing of iron took the form of industrial wage work and employed machines such as water-driven hammers, it was based on the artisanal skills of a forge crew who worked with such hammers. The crew consisted of a couple of smiths - one of them a master smith in earlier times - and a varying number of apprentices at different stages of their apprenticeship. Apart from the most basic tasks of lifting and the like, none of the skills of the men working in the forges could be replaced by industrial devices or mechanization. Thus, it was only logical that contemporary mill owners should regard the smiths as their most important production asset and often enticed them from other ironworks, even importing them from other countries, in a continuous struggle to find a professionally skilled workforce. In peripheral regions such as the Nordic countries, and especially in the more isolated parts like Finland, there was a constant scarcity of skilled ironworkers. ${ }^{28}$

The demand for their specialized skills led naturally to benefits for the smiths. They were generally the best-paid group of workers in ironworks communities. Their fringe benefits were extensive, including more spacious housing that was reserved exclusively for them, and small patches of land for subsistence farming. These represented considerable advantages in their standard of living in a community whose other members suffered greatly from cramped living conditions and an uncertain livelihood arising from seasonal fluctuations in the demand for labour at the ironworks. ${ }^{29}$ The smiths also enjoyed paramount social status among the labourers of the ironworks company, and this was manifested in everyday social interaction and the formation of exclusive local social networks. ${ }^{30}$ Family-historical

28. See for example Barbro Bursell, Träskoadel. En etnologisk undersökning av lancashiresmedernas arbets- och levnadsförhaillanden på Ramnäs bruk vid tiden kring sekelskiftet 1900 (Lund, 1974), pp. 64-66, 22 ; Anders Florén, "Some Comparative Remarks", in Göran Rydén and Maria Agren (eds), Ironmaking in Sweden and Russia: A Survey of the Social Organisation of Iron Production before 1900 (Uppsala, I993), p. I04; Rydén, Hammarlag och bushall, p. I 89; Vilkuna, Arkielämää patriarkaalisessa työmiesybteisössä, pp. 28, 33, 160-16I; Göran Rydén, "Skill and Technical Change in the Swedish Iron Industry, 1750-1860", Technology and Culture, 39 (1998), pp. 383-407, 407.

29. Bursell, Träskoadel, p. I78; Mats Larsson, Arbete och lön vid Bredsjö bruk. En studie av löneprinciper och lönenivaier för olike yrkeskategorier vid Bredsjö bruk I828-I90s (Uppsala, 1986), p. I 54; Sigvard Montelius, Säfnäsbrukens arbetskraft och försörjning 1600-1865. Studier $i$ en mellansvensk bruksbygd (Falun, 1962), p. 222; Rydén, Hammarlag och hushaill, pp. 232-236; Sirén, Strömfors, pp. 48, 58, 94.

30. Bursell, Träskoadel, pp. 77-78, 225; Vilkuna, Arkielämää patriarkaalisessa työmiesybteisössä, p. 51; Juuso Marttila, "Beyond the Family and the Household: Occupational Family Networks", Journal of Family History, 35 (2010), pp. I28-146. 
studies of the social environment of communities of this kind have found that many artisan networks were socially doubly knit, involving both a guild (occupation) and kinship (the inheritance of occupation and intermarriage). ${ }^{3 \mathrm{I}}$ This also held true in ironworks communities, where occupation and kinship were deeply entangled.

The position of smiths, especially those who did not attain the rank of master or later that of smith proper, may not have seemed enviable from a national perspective, but in ironworks communities the only persons who could boast a higher standard of living and status were those in managerial posts or church and government officials. In practice, all these more lucrative occupations were beyond the reach of ordinary members of the ironworks community and their offspring. To obtain such jobs they would have required an education that was not available locally, and thus social upward mobility was extremely limited. Moreover, there were relatively few who sought to rise in society by moving elsewhere. At the beginning of the twentieth century, only elementary schools were available in these isolated ironworks communities, and before that crude, albeit mandatory, teaching was provided only by local clergymen. Thus, the smiths had things as good as they could get in the context of their everyday lives, and it was only logical that they should seek to defend their position..$^{32}$ It is important to bear this in mind when comparing the behaviour of smiths with that of other European artisans, who are usually described in the relevant literature as constantly seeking a rise in status and welfare for themselves and their offspring.

The skills needed in forges were not available to everyone. They could be acquired only by taking the proper path from apprenticeship to mastery. This journey was originally guarded by the law governing the guilds and, after its abolition, by the smiths themselves. The law had provided for separate courts for ironworkers and stipulated detailed provisions concerning, among other things, the organization of work and the transmission of the property of skill. It had originally offered both the means and guidelines for craft control by strictly defining the organization of work and apprenticeship. ${ }^{33}$ The companies had no say over the training of the smiths: the masters had the freedom to choose their

31. Carola Lipp, "Kinship Networks, Local Government, and Elections in a Town in Southwest Germany, I 800-1850", Journal of Family History, 30 (2005), pp. 347-365, 358-362.

32. On limited social mobility in ironworks, see Vilkuna, Arkielämää patriarkaalisessa työmiesybteisössä, pp. 52-58. See also Florén, "Labour Conflicts in Proto-Industrial Iron Production", p. iा I.

33. The regulatory legislation referred to here was Kongl. Maj:ts Förnyade Hammar-Smeds Ordning, 26 June 1766 . It is important to remember that even if this legislation provided for guild-like corporative elements, they were different from other European guilds. For example, they guaranteed an influential role for the works' owners. See Florén, "Labour Conflicts in Proto-Industrial Iron Production”, pp. 89-90; Rolf Torstendahl, with Ludmila Dashkevich and 
apprentices themselves and also to decide when they had acquired enough skill to qualify as smiths. Even sparsely available vocational education could not offer the critical experience and the "eye" needed in the oldfashioned forge. Still, even after apprenticeship had become informal, shorter, and less uniform, it was still the only means of acquiring the required skills. ${ }^{34}$ In the long run, this made households the basic units of production, as forge crews often consisted of members of the same family, at least in the nineteenth century.

It was then only logical that they should strive to maintain and defend the position of their own household or close relatives. Since this depended on skills acquired through personal contacts, it led to the birth of a worker aristocracy, traditionally called a "clog nobility" (trädskoadel), from the wooden shoes worn by the smiths. Smith families closely associated themselves with other smith families in the same ironworks and also with the smiths of other ironworks as a result of the widespread habit of moving from one ironworks to another. The selection of apprentices was soon restricted to this personal community of smith families. ${ }^{35}$ This accords well with the observation of Leunig, Minns, and Wallis on London guilds that the accumulation of human capital was likely to be dynastic in circumstances where personal connections were critical. ${ }^{36}$ A good example in Strömfors is the Liihr family, which could boast an unbroken lineage of ironworking in Strömfors from the end of the r 770 s until the closure of the ironworks in 1950.

This development was stimulated by the traditional system of payment, in which the master smiths paid their crews. This encouraged them to keep the money in the family, although, on the other hand, it prevented less well-off smiths from taking on apprentices. Naturally, some smiths were more competent than others because of personal talent or better training. A smith's prestige depended almost completely on how skilled he was at working with iron, and, for example, in the Mariefors Ironworks in Finland a smith who could not work without machines was held in lower esteem. Differences in craftsmanship were also a significant factor with regard to remuneration, in that the payroll system was directly linked to skill. Piece wages were often paid, and skilled smiths also

Sergei Ustiantsev, “Knowledge: Its Transfer and Reproduction in Occupations”, in Ågren, IronMaking Societies, pp. 276-306, 28I.

34. Bursell, Träskoadel, p. 78.

35. Vilkuna, Arkielämää patriarkaalisessa työmiesybteisössä, p. I I 3; Florén, "Some Comparative Remarks", pp. 104-105; Rydén, Hammarlag och hushall, pp. I I-I60; Florén, Genus och producentroll, p. 33; Rydén, "Skill and Technical Change in the Swedish Iron Industry, I750-I 860", pp. 398-40I; Göran Rydén, "Iron Production and the Household as a Production Unit in Nineteenth-Century Sweden", Continuity and Change, Io (1995), pp. 69-104.

36. Tim Leunig, Chris Minns, and Patrick Wallis, "Networks in the Premodern Economy: The Market for London Apprenticeships, I600-1749”, in CEP Discussion Paper, no. 956, 2009, p. 2. 
benefited from compensation offered for coal saved in the work process. Thus, there was some inequality even among the smiths themselves when it came to the value and quality of their skill. ${ }^{37}$

Skill also played a fundamental role in the formation of a smith's personal and social identity, which in the pre-industrial era was strongly influenced by occupation. The nature of skill as property, as John Rule put it in 1989, was the most significant of the values that underlay the consciousness of skilled workers. James Farr similarly divided the artisan occupational identity, which was closely linked to the artisan hierarchy and position, into two basic processes: establishing boundaries with other trades and creating a subjective feeling of distinctiveness based on status and independence. ${ }^{38}$ All these elements were also present in ironworks communities. The community determined people's whole lives as well as the individual's daily routines, status, and standard of living. ${ }^{39}$ Both the skill itself and the opportunities it afforded set smiths apart from the rest of the local population and also gave them a feeling of pride. The property of skill and the ability to monopolize this bound local smiths into a coherent and exclusive social group.

All this also holds true conversely: labourers in other production units in ironworks, lacking as they did the craftsmanship and the social capital of the smith network, possessed no similar tools for constructing their occupational identity. Two statements concerning the period before the I940s in Strömfors Sawmill, which was part of the ironworks community, offer a sound reminder of this fundamental difference in skill between employees in the forges and in the sawmill: "When I started working in the sawmill, there was nothing to learn"; ${ }^{\circ}$ and "When I went to that job in the sawmill, I don't remember anyone giving me any instruction. I just looked on and watched how it was done."4I Thus, no special training was needed. These labourers also had no control over their own work.

Most of the above factors held true throughout the lifespan of the iron industry. Only from the latter half of the nineteenth century did the

37. Bursell, Träskoadel, pp. 72-74; Hanna Forssell and Gunilla Carlander-Reuterfelt, Ruukin elämää: Patruunoita ja työläisiä Kellokoskella (Helsinki, 2009), p. 63; Larsson, Arbete och lön vid Bredsjö bruk, pp. I53-1 56; Rydén, Hammarlag och hushäll, p. 244.

38. James R. Farr, Artisans in Europe, I300-I9I4 (Cambridge, 2000), pp. 4, 22, 43, $28 \mathrm{I}-283$, 286; Rule, "The Property of Skill in the Period of Manufacture", p. ı०4; see also Rydén, "Skill and Technical Change in the Swedish Iron Industry, I750-1860", p. 387; Merja Uotila, "Ammatti käsityöläisten identiteetin rakentajana I 800-luvun alun maaseudulla", in Laura-Kristiina Moilanen and Susanna Sulkunen (eds), Aika ja identiteetti. Katsanksia yksilön ja yhteisön väliseen subteeseen keskiajalta 2000-luvulle (Helsinki, 2006).

39. See Rydén, Hammarlag och hushäll, and Vilkuna, Arkielämää patriarkaalisessa työmiesyhteisössä, on the pervading influence of work in ironworks communities.

40. Ruotsinpyhtää Municipality Archives, Loviisa (hereafter RMA), Ruotsinpyhtään Ruukkialue Oy's archive (hereafter RMA-RRA): interview with Armi Lehto, 24 July 1998, p. 6. Translation of this quotation and all following quotations are by the author.

4I. RMA-RRA: interview with Reijo Johansson, 28 July I998, p. 6. 
importance of the smiths' craftsmanship gradually come under increasing threat. First the guilds, and the legislation supporting them, were abolished by decrees, in Finland in 1868 and in Sweden in 1846 . This deprived the smiths of an institution which had defended their privileges against both employers and outsiders trying to get access to their prestigious occupation. Then there were even more noteworthy consequences at the micro level, resulting from mechanization, which to some limited extent lessened the importance of personal skills in the production process and more importantly gave employers more power over the whole process.

Changes in the production process brought by a general transition to the Lancashire method likewise represented threats to the old labour structures. The scale of production was increased, and the distribution of work was expanded, which made the old ways of controlling production obsolete and brought supervisors to the forges. These developments also led further to the removal of the hierarchical organization of work, as, for example, in the case of the Skebo Ironworks in Sweden. In Skebo, this process, coupled with a strong influx of migrant workers, led to the breakdown of the old social networks based on the traditional organization of work. Changes in the industry also contributed to the fact that the number of masters began to decline, which in itself upset the old intra-guild hierarchy, or rendered it largely redundant. Moreover, changes in the overall economic situation of the ironworking industry affected the local situation as a highly successful period of expansion was soon followed by a period when most of the ironworks ceased their activities. This led to a situation in which there were no longer enough ironworks to employ all of the smiths. ${ }^{42}$

Most ironworks communities faced major changes as a result of these new conditions. However, they generally did not affect Strömfors, or did so only marginally. This enables us to distinguish the change brought by the cessation of regulation more clearly there than in some other ironworks. The research is further facilitated by the protection of the Strömfors smiths from the effects of some of these changes by the retention of older techniques and the fact that the only machinery used continued to be water-powered hammers. Only the titles "master smith" and "apprentice" were gradually dropped in the last few decades of the nineteenth century and replaced with "smith" and "sälli" [informal apprentice]. Special skills were still needed for the production of iron goods, and the forge, under the guidance of an experienced smith, was the

42. Kersti Morger, Skebo bruk. Teknisk och social förändring vid ett järnbruk under I 870-talet (Stockholm, 1985), pp. 264-265; Bursell, Träskoadel, pp. I IO-I I I; Montelius, Säfnäsbrukens arbetskraft och försörjning I600-I865, pp. 221-222; Anders Florén, Maths Isacson, Göran Rydén, and Maria Ågren, "Swedish Iron Before 1900", in Rydén and Ågren, Ironmaking in Sweden and Russia, pp. 38-39; Rydén, "Skill and Technical Change in the Swedish Iron Industry, I750-1860". 


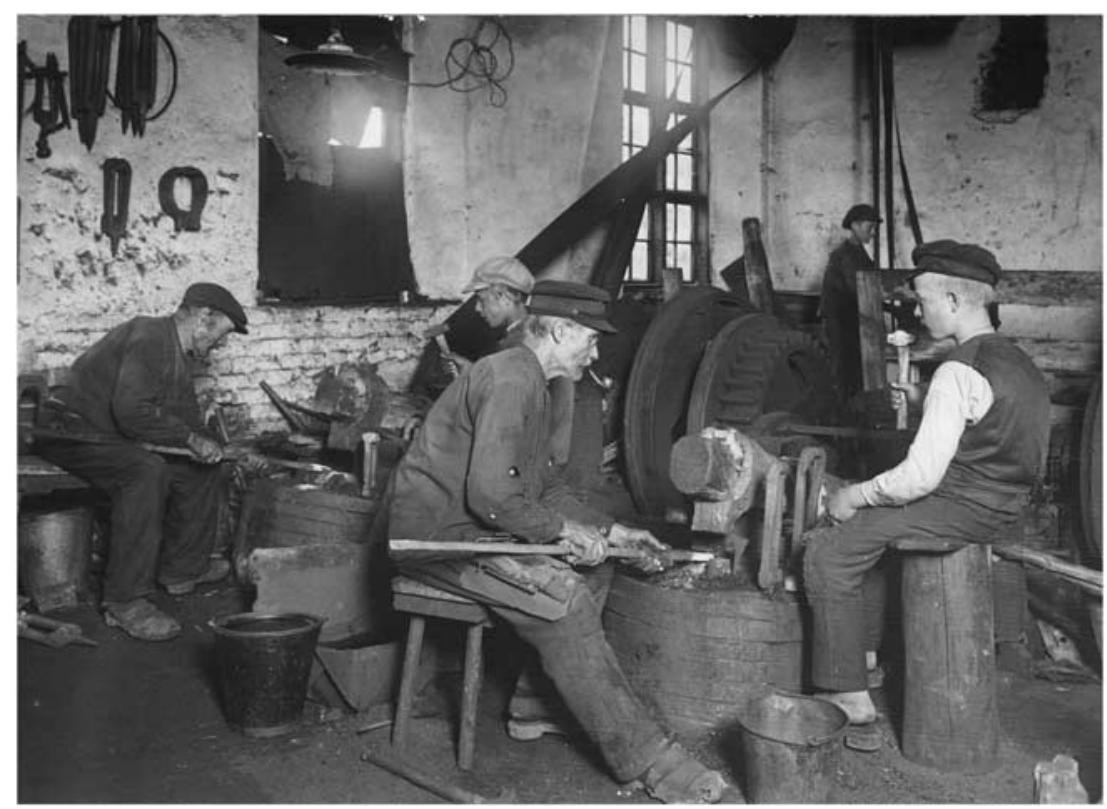

Figure I. Young men from the Forsten and Forsberg smith families learning the nail-making trade in Strömfors Ironworks as informal apprentices in the I920s. The working methods and organization of work had remained the same for hundreds of years.

A. Ablström Oy archives, Noormarkku. Used with permission.

only place to acquire such skills. Thus, an informal apprenticeship system and craft closure continued to be maintained locally in Strömfors.

The practices provided for by the old legislation were still mostly followed, except that from the early twentieth century onwards the company took care of paying the informal apprentices. ${ }^{43}$ Figure I shows all this. In what follows, an in-depth analysis of the Strömfors Ironworks will reveal more closely the mechanisms that enabled craft closure to function and transmit the property of skill involved from generation to generation without any formal institutional protection, whether provided by the state, guilds, or unions.

\section{SMITH FAMILIES AND THE PROPERTY OF SKILL IN STRÖMFORS}

As in most of the ironworks of the nineteenth century, a typical smith in the Strömfors Ironworks from the I880s to the I940s was, as had been 
customary for centuries, the son or a close relative of another smith. The research literature on ironworks is unanimous that this kind of occupational heredity was the standard practice in ironworks and that the custom was still alive even in the early twentieth century in some latesurviving forges such as the Mariefors Ironworks. ${ }^{44}$ It was not only the first-born son who inherited a smith's occupation: in Strömfors a smith whose father, son, and two brothers were all smiths was in no way exceptional at the turn of the century, as can be seen in Figures 2 and 3. A couple of these families could trace a descent in forging going back hundreds of years. Figure 2 in particular well illustrates how strong the tendency to keep specialized human capital in the family was throughout the period studied. The overall picture of smith families in Strömfors in the period I $880-1950$ is presented in Table $2 .{ }^{45}$

In addition to the families in Table 2 , in the period I880-1950 there were also ten to twenty smiths who came from other ironworks and were employed in the Strömfors forges for only a couple of years before continuing on their way. This was customary in the ironworks industry, where men moved between ironworks in search of both informal apprenticeship and, more importantly, a job at a time when the demand for a smith's skills was decreasing nationwide. The forge workers who passed through Strömfors and a few of those who came from other ironworks and settled there were already smiths and as such represented the established model. As they played no part in transmitting the skill locally, they have been excluded from Table 2. There were also a few other smiths who had taken up the occupation under the old apprenticeship system and whose families gave up forge work in Strömfors during that period. Usually this was because they had no male offspring, or, if they did, these had moved away from Strömfors.

Interestingly, three of the families in Table 2 established themselves in Strömfors from Sweden only shortly before the i 880 s, and the last smith family to settle more or less permanently in Strömfors came there in I 882 . This is a reflection of the situation in the Swedish iron industry, as Swedish smiths moved to Finland in large numbers in search of employment. It is interesting that these smiths, who were accustomed to journeying between different ironworks, managed to establish a local monopoly over the property of skill without institutional protection. In I 880 ten out of the nineteen smiths in the forges were from families in Table 2. At least six of the remaining smiths had come as immigrants from Sweden within the same

44. See, for example, Rydén, Hammarlag och hushall, pp. is I-160; Florén, Genus och producentroll, p. 33; Bursell, Träskoadel, pp. 72-74; Forssell and Carlander-Reuterfelt, Runkin elämää, p. 58 .

45. Ebba Dahlström and Olle Dahlström, "Släkten Lihr under 350 år”, Uppsatser: Skrifter utgivna av Helsingfors släktforskare, 6 (1984), pp. 103-149. 


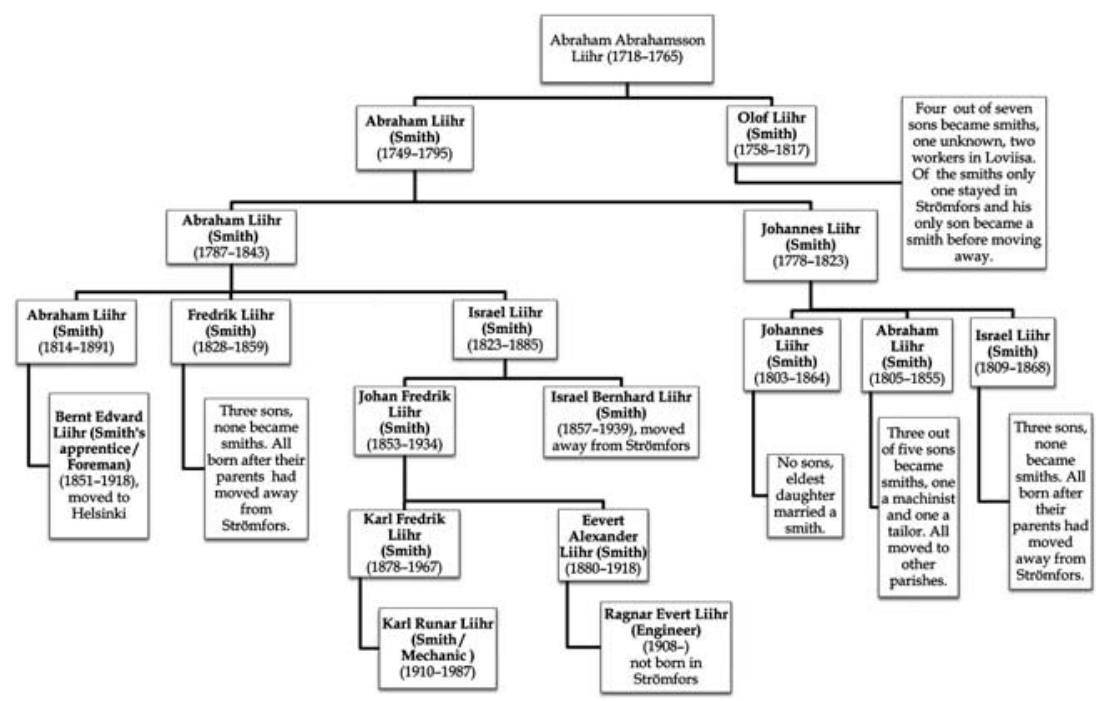

Figure 2. The Liihr family (male line), the most notable smith dynasty in Strömfors. It should be noted that some members of the family did not remain at the Strömfors Ironworks but moved to other ironworks after becoming smiths. The figure includes only descendants of smiths whose offspring lived in Strömfors for at least a short time. Sons who died before getting an occupation are also excluded.

Ruotsinpybtää (Strömfors) church archive, communion records $1780-1950$.

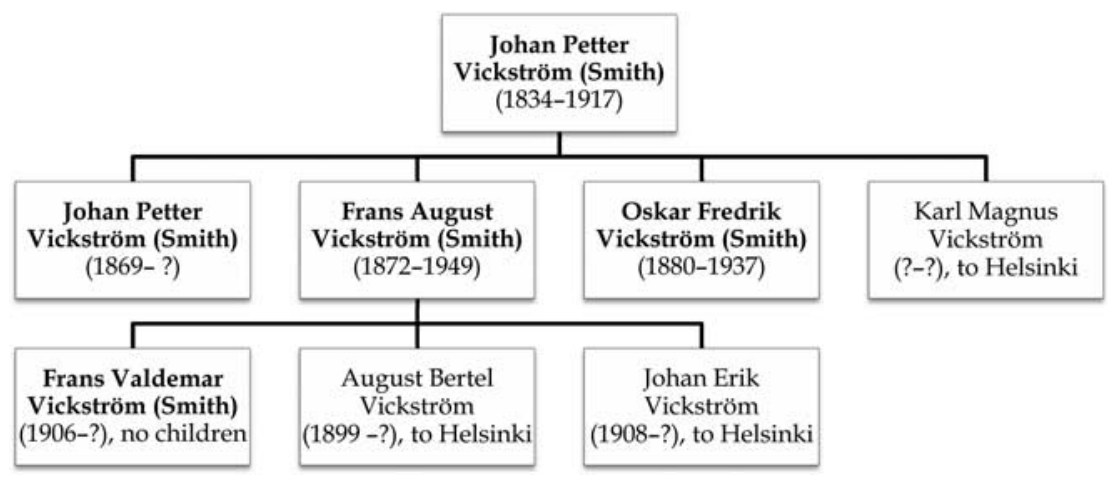

Figure 3. The Vickström family, (male line), an example of a family arriving in Strömfors and successfully establishing itself.

Ruotsinpybtää (Strömfors) church archive, communion records I848-1950.

short period of time, and were members of the group mentioned in the paragraph above who either most often moved on or did not have sons who stayed in Strömfors. The local nature of this monopoly becomes evident in I9I3, when we see that twelve out of thirteen smiths in Strömfors were 
Table 2. Smith families at Strömfors Ironworks i 880-1950

\begin{tabular}{|c|c|c|c|c|c|c|}
\hline Family & $\begin{array}{l}\text { Year of entry to } \\
\text { Strömfors forges }\end{array}$ & Year of exit & $\begin{array}{l}\text { Number of } \\
\text { generations }\end{array}$ & $\begin{array}{l}\text { Number of } \\
\text { males* }\end{array}$ & $\begin{array}{l}\text { Number of } \\
\text { smiths }\end{array}$ & $\begin{array}{l}\text { Number of adult males } \\
\text { staying at Strömfors but } \\
\text { not working in forges }\end{array}$ \\
\hline Liihr & Before 1880 & At closure & 4 & 12 & 10 & 0 \\
\hline Forsberg & Before 1880 & At closure & 2 & 5 & 4 & 1 \\
\hline Forstén & 1882 & At closure & 3 & 8 & 5 & 3 \\
\hline Vickström & Before 1880 & At closure & 3 & 8 & 5 & 0 \\
\hline Grönroos & Before 1880 & 1946 & 2 & 3 & 3 & 0 \\
\hline Blomqvist & Before 1880 & 1943 & 2 & 2 & 2 & 0 \\
\hline Lindholm & Before 1880 & 1912 & 2 & 6 & 4 & 0 \\
\hline Jäderberg & Before 1880 & 1892 & 2 & 4 & 3 & 0 \\
\hline
\end{tabular}

* Refers to the number of males who reached the age of maturity in Strömfors and were thus available as apprentices. Source: Strömfors church archive, communion records i 879-1950. 
members of the families represented in Table 2. Most importantly, with two exceptions, none of those who had acquired the trade in Strömfors from the I 880 s to the late I930s had ancestors who were not smiths. This matter will be addressed below. ${ }^{46}$

It is also evident from Figures 2 and 3 and Table 2 that even if not all descendants of the Liihr family, not to mention other families, were able to find work in the Strömfors Ironworks, a non-craft occupation was an option only when a man moved away from Strömfors or was born in another locality. Naturally, a conflict between a father and a son could also result in the latter leaving. ${ }^{47}$ Even those who left often worked as smiths in other localities or tended to choose a craft-related occupation in cities such as St Petersburg and Helsinki. This opportunity for relocation strengthened the relative position of smiths and their offspring. As can be seen in Table 2, in only two locally established smith families (the Forsbergs and the Forsténs) did sons of smiths remain in the Strömfors Ironworks having failed to become smiths. It is noteworthy that all of them reached maturity in or after the rgros and that both families had a large number of male offspring. This testifies to the success of the monopolization of the property of skill in Strömfors and the benefits it brought to participating families.

Although the figures and the table above take only the male lines of the families into account, it is important to remember that females, too, played a part in this lineage of skill. The daughters of smiths tended to marry members of other local smith families even though the small size of the community and the prohibition on marrying close relatives (intermarriage even between cousins was discouraged) restricted this practice..$^{4}$ Altogether, we can positively identify at least ten couples married in the period I860-I900 in which both spouses were descended from smith families. These links secured the status of daughters. This is confirmed by regular instances of the daughters of smiths being married off to other well-off (at least compared to labourers) local families, such as the Backmans (the local millers).

Marital links and godparent connections also played an important part in keeping up the internal cohesion of this local network of smiths as well as in maintaining the exclusion of lower-class labourers. This is striking, especially since the proportion of other workers increased sharply towards the turn of the century. It clearly shows that smith families succeeded in

46. It should be noted that the figures in this paragraph refer to the number of households whose head was a smith. Consequently, more than just one smith or informal apprentice could be living in such a household. This was naturally more likely to be the case in established families.

47. RMA-RRA, interviews with smiths: interview with Hedda Saxbäck, I6 October 200 I. 48. On occupational endogamy in ironworks communities, see Vilkuna, Arkielämää patriarkaalisessa työmiesybteisössä, pp. 68-70; Rydén, Hammarlag och hushåll, pp. 2 I 2-2 I 3. See also Jan Sundin, "Family Building in Paternalistic Proto-Industries: A Cohort Study from Nineteenth-Century Swedish Iron Foundries", Journal of Family History, I4 (1989), pp. 265-289. 
remaining a separate integral clique without guilds. The role of local connections (and families) from the r 880 os on is emphasized by the fact that the last new family of smiths established itself in Strömfors in I 882. The solidarity within this group of smith families can be seen clearly from the fact that they managed to maintain the craft closure. This accords well with previous findings, presented by Martin Dribe and Patrick Svensson among others, concerning the importance of inheritance and inherited connections for the accumulation of human capital. ${ }^{49}$ This was especially true in an environment like Strömfors, where the opportunities to exploit human capital were limited, and thus the findings here differ considerably from those for London, for example, which downplay the importance of family connections for the apprenticeship system. ${ }^{50}$

Family connections and internal cohesion of smith families also proved important in a few cases where there was a male in the second generation who was not a smith but the human capital was still accessible to the third generation. In these cases, either the connection with the old smith families was direct through the mother, or at least the family continued to be strongly involved in the network of smith families through marriage and godparent connections, as in the case of Johannes Forsberg. His family had strong traditions of iron-making in Strömfors, but for some unknown reason his father had not worked in the forges. Moreover, Johannes's grandfather, a smith, had died before Johannes was born. However, his sister was married to a smith, and the godparents of his siblings also included several smiths. These links gave Johannes access to the craft and admission to the forges, where he and his offspring made successful careers. Interestingly, Johannes's eldest son was remembered for his skill as the last of the true forge masters. ${ }^{5 \mathrm{I}}$ Marital links also played an important part in bringing smiths from other ironworks to Strömfors. For example, after an earlier short stay, the Vickström smith family moved back to Strömfors when Johan Petter Vickström married a daughter of Abraham Liihr (b. i805).

Local networks and their connections, reinforced by marital links and godparent relations, also help us to understand the only significant exception to the rule in the Strömfors forges. The turn of the century brought Axel Alfred Borgman, a son of an established family of charcoal burners, to the forges. In looking at local social connections, the charcoalburner families appear as some sort of intermediary group between smiths and non-skilled labourers. They partook in a distinctive godparenting system in which both smiths and employers were present on equal terms

49. Dribe and Svensson, "Social Mobility in Nineteenth Century Rural Sweden", pp. I26-I 28. 50. Leunig, Minns, and Wallis, "Networks in the Premodern Economy", pp. 6-8.

5I. RMA-RRA, interviews with smiths: interview with Erkki Markkanen, 5 October 1994; interview with Sauli Ek, 26 November 1997; interviews with Gösta Backman, Lauri Klingberg, Aarne Seppälä, Erkki Markkanen, and Ahti Rikberg, I4 June i99ı. 
(both as godparents and godchildren). This clearly indicates stronger connections with the smiths than with unskilled workers, as these godparent relations seem to have been more or less bilateral. ${ }^{52}$ There were also some marital links with smiths. The craft skill of charcoal-burning also seems to have been inherited, although not nearly as extensively as that of the smiths. All of these factors are indicative of an artisan-like identity separate from the ordinary workforce, albeit one less clear and pronounced than in the case of the smiths.

The significance of the artisan heritage of an outsider getting into forge work is also emphasized by the only other case before the I930s, where a man from a non-smith family background got to work as a smith in the forges. $\mathrm{He}$ was a Swedish carpenter. Presumably, both these factors - belonging to an occupation that demanded some special skill, and prior connections with the smith network - made it possible for Borgman to become a smith. Even so, one significant difference between him and "regular" smiths remained: none of Borgman's numerous children inherited his trade.

Finally, towards the I940s, true outsiders start to appear in the records as smiths or as informal apprentices. The period between the two world wars saw a gradual decline in the demand for handcrafted iron products, and because of this only a few new employees started working in the forges. These continued to be engaged from the most-established smith families, such as the Forsténs and the Forsbergs, and no recruitment from the other few still functioning ironworks was needed. Because they realized that ironworking was slowly dying out even in Strömfors, most of the offspring of smiths' families had moved away in order to put their inherited skills to use when the outbreak of World War II and its aftermath suddenly caused a surge in the demand for iron goods. The local demand for handcrafted iron goods made from scrap metal increased, and, at the same time, the few younger smiths who were available were drafted into the army. The management at Strömfors reacted swiftly, though not without first consulting the smiths, and very soon more than ten new employees came to work in the forges, most of them without any observable connections with local smith families. ${ }^{53}$

Apart from the shared work itself, the newcomers' links with the older guard of smiths were fragile at best. The newcomers were mostly Finnishspeaking, whereas traditional smith families had kept up the use of Swedish even after Finnish had become the main language spoken in the community. ${ }^{54}$

52. A more in-depth analysis of godparent data is presented in Marttila, "Beyond the Family and the Household".

53. Sirén, Strömfors; RMA-RRA, interviews with smiths: interview with Lauri Klingberg, 25 November 1997.

54. The distinction here is almost completely linguistic, not ethnic, although some of the Swedish-speaking families had migrated to Strömfors from Sweden. 
The new employees also never managed to become fully integrated into the old community, which is clearly reflected in the fact that only a couple of them earned the title of smith. ${ }^{55}$ More importantly, they were not taught enough to carry out more delicate jobs. The older smiths guarded their precious human capital and taught only the basics needed to do the simplest jobs. They did not even lend their tools to the newcomers, who had to make their own. The treatment meted out to the new employees was often in stark contrast to that afforded to those offspring of smith families who still came to work in the forges and got better training, quicker advancement, and more important tasks during their apprenticeship. ${ }^{56}$ "Even confirmation school was easier for [informal] apprentices. We just went to exams, and the rest of the time we had leave to go to work", said the last smith from the Forstén family, who had gone to work as his father's apprentice in the late I930s. ${ }^{57}$

\section{MEANS AND MOTIVATION FOR MAINTAINING THE PROPERTY OF SKILL}

The emergence of this new and last group of ironworkers and the reluctance to train them reveal how little, in fact, had altered in Strömfors in the twentieth century, despite the changes in the surrounding environment. It is, indeed, questionable how much of this training system had originally relied on the guilds, as guild masters and aldermen had been rare visitors to Strömfors. For example, in 1829 the owner of the ironworks complained that his smiths had not received any teaching from an alderman in forty years. ${ }^{5}$ Thus, the abolition of the guilds did not mark an end to means to maintain the property of skill. Even if, in the last decade of ironworking, it was no longer possible to impose a complete monopoly of craft skill when management recruited new groups of workers, the smiths were still able to control their exclusive human capital. The old style of training, that of informal apprenticeship, was still the only way, and the smiths controlled what they taught and to whom. "Johannes did what he wished, the rest did what they could", was how one of the newcomers described the situation in the I940s, referring to

55. See, for example, RMA-RRA, interviews with smiths: interview with Timo Forstén, n.d.; interview with Sauli Ek, 6 October 1994; interview with Gösta Backman, 3 December 1997; interview with Lauri Klingberg, 25 November 1997.

56. Börje Broas, personal archive: interview with Lauri Leo Klingberg, is September 2000. RMA-RRA, interviews with smiths: interview with Lauri Klingberg, n.d.; interview with Gösta Backman, 3 December 1997; interview with Erkki Markkanen, 5 October 1994; interview with Aarne Seppälä, 1994; interview with Sauli Ek, 6 October 1994; interview with Lauri Klingberg, 25 November 1997. Juuso Marttila’s personal archive: interview with Aarne Seppälä, I3 September 2006.

57. RMA-RRA, interviews with smiths: interview with Timo Forstén, n.d.

58. Sirén, Strömfors, p. 50. 
differences in skill between Johannes Vilhelm Forsberg, a smith of the old guard, and the newcomers. ${ }^{59}$ The skill of the old smiths was regarded as phenomenal, as the remark of Timo Forstén shows: "The [waterpowered] hammer used to make nails struck really fast. The youngsters couldn't keep up with it, but the old smiths even had time to smoke between times."

Moreover, the company's overseers could still not exert any control over the quality of the work or the work process itself in the forge, apart from distributing orders from customers according to the skill levels of the smiths. Even an effort to install a supervisor in the forges from outside to oversee the work fell through when he failed utterly to obtain the respect and trust of the smiths and lacked the knowledge to control the quality. A good example of this is provided by the fact that, when the company finally introduced drills and welding machinery in the forges in I947, the smiths simply refused to use them. The smiths also managed to obstruct some other managerial decisions through negotiation or by threatening to leave the forge. For example, Johannes Vilhelm Forsberg got management to cancel the appointment of his able apprentice Ahti Rikberg to the post of chauffeur, and even ensured Rikberg was given a higher salary. All in all, the smiths enjoyed considerable freedom over their work, up to the very end. The old traditions seemed to take them a long way even after the significance of ironworking, the former basis for their focal position, had gradually almost vanished. ${ }^{61}$

One important aspect of this was that the overseers and management in general never needed to seek ways to break open the craft closure or to make a more concentrated effort to exert control over the production process. The mutual trust between the smiths and management was maintained throughout the period, and no large-scale polarization existed between local management and the smiths as a collective body. A good indication of this is provided by the fact that the trade unions only got a foothold in the community at the end of the 1940s. ${ }^{62}$ The mutual trust was also strengthened by personal ties: an overseer of the ironworks was married to a daughter of a smith. The maintenance of the old patriarchal style of leadership in general must also have been a contributory factor. The acceptance of patronage - and, from the point of view of the company,

59. RMA-RRA, interviews with smiths: interview with Erkki Markkanen, 5 October 1994.

60. RMA-RRA, interviews with smiths: interview with Timo Forstén, n.d.

6I. RMA-RRA, interviews with smiths: interview with Erkki Markkanen, s October 1994; interview with Sauli Ek, 6 October 1994; interview with Lauri Klingberg, n.d; interviews with Ahti Rikberg, 27 October 1994 and 9 November 1994; interview with Sauli Ek, 26 November I997; RMA-RRA, heritage interviews I968: interview with Gunnar Toivonen.

62. Juuso Marttila's personal archive: interview with Aarne Seppälä, I 3 September 2006; RMARRA, interviews with smiths: interview with Armi Lehto, 24 July 1998. 
the offer of it - crucially limited both the scope and the need for social movements, including trade unions, in Strömfors. ${ }^{63}$

Another important factor was that the informal apprenticeship system seems to have been more than capable of guaranteeing an adequate workforce in such a declining, small workshop, at least until the I940s, and even after that new employees were recruited from within the community. ${ }^{64}$ The old system performed well enough in an industry that had already become of secondary importance for the company. In a good year like 1927, the company could obtain an almost 45 per cent return on sales, so its economic performance was fairly good. ${ }^{65}$ Since the old organization of work based on work teams was maintained, the process of learning the job was still built into the production process. This made it possible and also necessary to continue the practice of informal apprenticeship, thereby concomitantly maintaining the old exclusiveness of the craft skill as long as established smith families could still offer youngsters to work in the forges.

The favourable economic circumstances also made it possible for the network of old smith families to maintain their craft closure. A demand for handcrafted iron products, although in constant decline in the twentieth century, stayed at a high enough level to cause the ironworks company every now and then to recruit a new smith - naturally from one of the established smith families - to replace retiring smiths. Even though the number of smiths recruited was relatively low, and many of the sons of these families had to turn to other occupations, this recruitment still helped the old property of skill to survive. A network of families was also a more adaptable instrument for implementing this closure than a union, which would have encountered challenges in the face of this gradual decline. ${ }^{66}$

The decline also helped to maintain the closure of the smiths' skill far better than the sudden increase in demand in the I940s did, which in this case proved just too short-lived to affect it, with the result that forges were closed in 1950. A similar surge in demand happened, for example, in the Finnish glassblowing industry, which possessed a strikingly similar informal apprenticeship system, an artisan identity, and a hierarchy derived from a very similar organization of work. There the increased need for new recruits led to the collapse of the old hierarchy as newcomers simply had to be properly trained in order to cope with the ever-increasing production quotas. Changes in the organization of work in glassworks also undermined the old occupational networks. Newcomers in that industry had

63. Van der Linden, "Connecting Household History and Labour History", p. I7 I.

64. In larger organizations, informally structured apprenticeship tended to fail; Patrick Wallis, “Apprenticeship and Training in Premodern England", Journal of Economic History, 68 (2008), pp. 832-86I, 855.

65. Sirén, Strömfors, p. 74.

66. Van der Linden, Workers of the World, p. 238. 
more time than the outsider apprentices in Strömfors in the I940s to change the social landscape of the working community, which had likewise previously been characterized by unequal career opportunities and income. ${ }^{67}$

However, possession of both the means and the situational possibility to maintain the property of skill would not have been enough if there had not also existed the motivation to do so. In Strömfors, Finnish wage reforms that aimed to stop the practice of granting extensive perquisites were for a long time either opposed or simply ignored. The old smith families continued to enjoy advantages that were unsurpassed at the local level: "Smiths had better perks, better two-room homes, better pastures, free hay, and arable land for potatoes", Hilma Klingberg stated, in a recollection that generally applied to the whole period. ${ }^{68}$ Even after the practice of perks declined and remuneration was made more equitable over the whole community, the payment of piece wages continued to favour the old smiths right up to the end.

The more demanding, and thus more profitable, jobs were always given to those who were skilled enough, i.e. the old smiths, who still earned piece wages. The old smiths continued to be the best paid group of the company's employees right up until the closure of the ironworks. Even in the last few years of the Strömfors Ironworks, older smiths earned on average is to 30 per cent more than younger smiths, who generally did not come from smith dynasties. Even some of those few newcomers who finally became employed as smiths proper did not reach parity with the older smiths in terms of income until 1948, and apprentices lagged far behind right up until the end of ironworking. In I948, smiths' wages were pretty much in line with the national average income for artisans. ${ }^{69}$

However, one should not look exclusively at the financial motivation. It is all too easy then to forget that membership of this "clog nobility" was an important part of their identity, and, as far as we can tell, the situation had remained almost unchanged from the early seventeenth century onwards. Apart from some of the latest newcomers, the smiths shared an artisan-like occupational identity, and they were proud of it. This kind of shared pride was often attached to artisan occupations. ${ }^{70}$

67. Nurmi, Lasinvalmistajat ja lasinvalmistus Suomessa; Virpi Nurmi, "Työväkeä vai käsityömestareita? Lasinvalmistusta I 900-luvun alkupuolella”, in Raimo Parikka (ed.), Suomalaisen työn historia. Korvesta konttoriin (Helsinki, I999).

68. RMA-RRA, heritage interviews I968: interview with Hilma Klingberg, n.d.

69. RMA, III ıо, Bb, Taxation records for Petjärvi and Vähä-Ahvenkoski (1946-1948); Suomen Virallinen Tilasto IV B Is, Table 9; RMA-RRA, interviews with smiths: interview with Erkki Markkanen, 5 October 1994; interview with Lauri Klingberg, 1994. Exact comparisons with artisans elsewhere are hard to make, especially for earlier dates, because of the complicated perquisite system.

70. Even most of the newcomers felt that they were part of something special that set them apart from ordinary employees; Juuso Marttila's personal archive: interview with Aarne Seppälä, I3 September 2006; interviews with Erkki and Salli Markkanen, I3 September 2006. 
It was important to Johannes Forsberg that the lump of iron he took was precisely the size he needed, so he would not need to cut any surplus off at any stage. His work pieces were always precise and beautiful, of a similar size, and in every respect just like they had been made with a mould,

was how one smith, Ahti Rikberg, described the work of Johannes Forsberg, one of the last true custodians of the property of skill. ${ }^{7 \mathrm{I}}$ It was this property that the smiths wanted to transmit to their offspring as a heritage.

Importantly, in Strömfors smiths were respected right up until the closure of the ironworks, and to some degree even afterwards. Regardless of whether they had been employed in the sawmill or the smithy, all the informants interviewed during the latter half of the twentieth century were very insistent when they were asked about this. "The smiths were a law unto themselves [...] they did whatever they liked, they were lords compared to the folk of the sawmill. [...] the smiths were still a cut above others", was how one interviewee from the sawmill described the position of the smiths in the last few years of ironworking. ${ }^{72}$ In a community with a traditional social hierarchy that affected virtually everything, belonging to this upper stratum of the hierarchy must have been an important factor in motivating the smiths to keep the trade in the family - or more importantly the family in the trade. ${ }^{73}$

The significance of means and motivation is emphasized when the situation in Strömfors is compared with that of the ironworks in Ramnäs, the last traditional Swedish ironworks. There, mechanization progressed swiftly, changed the organization of work, and reduced demand for craft skill. The organizational system based on teams was replaced with one more suited to an assembly-line process than to the old cooperative craftwork. The smiths also gradually lost their advantage in wages over other employees. These losses were compounded by smaller changes that made it ever harder for the smiths to stand out from the rest of the community and which also threatened their occupational identity. The property of skill was lost, and some smiths actively discouraged their sons from taking up jobs in the forges. These changes broke the centuries-old trust between the smiths and the new management, and the acceptance of patronage became an unacceptable option. Consequently, trade unions, with smiths as their leading figures, became the primary strategic tool for improving living and working conditions in Ramnäs. ${ }^{74}$

7I. RMA-RRA, interviews with smiths: interviews with Ahti Rikberg, 27 October 1994 and 9 November 1994.

72. RMA-RRA, interviews with smiths: interview with Armi Lehto 24 July 1998, p. 5 .

73. RMA-RRA, interviews with smiths, and interviews with sawmill workers.

74. Juuso Marttila, "Pääomien leikkauspisteessä. Seppäyhteisön erityisasema ja sen kohtalo Strömforsin ja Ramnäsin rautaruukeissa vuosina I880-1970" (M.A. Thesis, University of Jyväskylä, 2006), pp. 79-8 I, 94-95; Bursell, Träskoadel, pp. I42-I 43, 206. See also Rydén, "Skill 
When ironworking finally ceased in Strömfors in the 1950s, one would expect the property of skill to have faced immediate disaster. However, the considerable level of mutual trust in the company did not disappear. Many smiths or their offspring were asked personally by overseers to hold responsible, or at least skill-demanding, positions in the new factory. ${ }^{75}$ The human capital part of the heritage passed on to later generations is even more clearly visible in the occupations of the offspring of smiths who moved elsewhere. Even though they fall outside the scope of this article, preliminary results show that a considerable number of them ended up as machine smiths, engineers, and in other human-capital-intensive occupations. This is very similar to the development in Britain, where, when threatened by innovations, the labour aristocracy branched out, abandoning their former class and crafts. ${ }^{76}$ Even though the craft closure more or less ended with traditional ironworking, the property of skill, albeit involving partly different skills, to some extent lived on.

\section{CONCLUSIONS}

The case of Strömfors, which in the period I880-1950 represented a typical traditional Scandinavian ironworks community, shows that a local property of skill and a strong artisanal heritage monopolized by a certain group of families were able to exist without the backing of any formal institutions. Despite the abolition of the guild system by the state in the late nineteenth century and the lack of unionism before the I950s, smiths in the Strömfors Ironworks were both willing and able to continue conserving, controlling, and passing on human capital in the manner familiar from the time the guilds were abolished right up until the closure of the forges in the early i950s. Even other national institutional changes, such as wage reform, did not here affect local practices, which overrode them for a long time.

This monopolization of a property of skill existed because favourable local circumstances offered a suitable setting as well as the proper means and motivation for it. Firstly, in traditional ironworking, the smiths' skill was an irreplaceable asset, and there was no way to obtain these skills other than by learning them from an experienced smith. Since the organization of the work required specific work groups (forge crews), informal apprenticeship was a natural result of the circumstances. Secondly, as the smiths' families were able to provide enough recruits to maintain reasonably

and Technical Change in the Swedish Iron Industry, 1750-1860”, pp. 405-406. On sons being discouraged from taking up work in forges in Ramnäs, see Språk- och Folkminneinstitutes arkiv, Uppsala Landsmålarkiv, ULMA 26380: I, interview with Karl Anton Lundberg, I 966. 75. PDS; RMA-RRA, interviews with smiths: interview with Timo Forstén, n.d. 76. See Hobsbawm, Workers: Worlds of Labor, p. $25 \mathrm{I}$. 
profitable, albeit old-fashioned, production, the situation worked well enough for the management.

Although the managers were unable to control the work on the shopfloor, they and the smiths enjoyed a relationship of mutual trust. It was this mutual trust in particular and the prevailing patriarchal system of management that made the company's leaders willing to prolong the situation. Thirdly, the smith's occupation offered the best economic and social position generally accessible and available within the community to smiths and their offspring. This offered a strong incentive for these families, with their strong mutual solidarity, to monopolize the property of skill. This was further reinforced by their long artisanal traditions and a strong occupational identity, which died hard even in the twentieth century. In this kind of environment one might ask whether guilds would even have been necessary for the formation of such a property of skill and its monopolization.

It is striking to note how similar the features in Strömfors were to those in the British and American cotton industry, as described by Isaac Cohen. In the more or less ideal situation in Strömfors it was also possible for the smiths to sustain their control without unions. One of the key differences in Strömfors compared with Cohen's case of the American cotton industry was the slow pace of change there, in contrast to the rapid pace of technological improvement that undermined the position of the American mule spinners. ${ }^{77}$ Even so, when we take into account the supreme importance that Cohen and other researchers have attached to unions in preserving the subcontracting system and the position of artisans, the case of Strömfors may seem puzzling. The question becomes even more intriguing when we note that the smiths' control in Strömfors was based on exactly the same principles, for example, concrete skills, that workers generally need in order to establish a trade union. ${ }^{78}$

The answer to this puzzle can be found by following Marcel van der Linden in connecting households and their strategic options to labour history. Of the four possible strategic resources listed by Van der Linden (reliance on relatives, personal communities, the acceptance of patronage, and involvement in social movement organizations), all, except social movement organizations, were present and utilized in Strömfors. There was simply no need for labour activism, or even room for it, in such circumstances. This study confirms Van der Linden's argument that the involvement of working-class households in labour activism is always determined by multiple factors, many of which depend directly on local circumstances. ${ }^{79}$

77. Cohen, "Workers' Control in the Cotton Industry", pp. 59-66.

78. Van der Linden, Workers of the World, pp. 229-230.

79. Idem, "Connecting Household History and Labour History", pp. I69-173. 
Even so, Strömfors appears to have been a fairly ideal setting for utilizing the possible strategic resources, apart from social movements. Above all, it reminds us that institutional protection, such as that provided by guilds or unions, was not always necessary, and that local circumstances could offer other means to create or maintain such a monopolized property of skill. For example, if some element in this situation had been missing, especially the smiths' relationships with management, it is easy to see that there would have been a need for union support in fighting for the workers' rights. Moreover, the role of technological change remained non-existent in Strömfors, but this often played a major role elsewhere. Thus, further research, possibly on other ironworks communities in Scandinavia, is still needed to better evaluate the weight of different factors behind these options and to provide more empirical information about household-centred forms of labour structures. 